\title{
Spectrophotometric Method for the Determination of Copper (II) in Leafy Vegetable, soil, Alloys and Pharmaceutical Samples Using 3-methylthiophene-2-carbaxaldehyde-3-thiosemicarbazone (3-MTAT)
}

\author{
G. Sreenivasula Reddy*, P. Raveendra Reddy \\ Department of Chemistry, Sri Krishnadevaraya University, Anantapur, India-515003. \\ *E-mail address: g_sreenivasula_reddy@yahoo.co.in
}

Keywords: Copper (II); leafy vegetables; Soil; Alloys; pharmaceuticals; 3-methylthiophene-2carbaxaldehyde-3-thiosemicarbazone (3-MTAT); spectophotometric method; and AAS

\begin{abstract}
A highly sensitive spectrophotometric method has been developed for the determination of copper (II) using 3-methylthiophene-2-carbaxaldehyde-3-thilosemicarbazone (3MTAT) as an analytical reagent. The 3-MTAT forms reddish brown species of copper (II) at a pH range of 5.0-7.0. The $\mathrm{Cu}$ (II)-3-MTAT complex shows maximum absorbance at $430 \mathrm{~nm}$, with molar absorptivity and Sandell's sensitivity being $1.6 \times 10^{4} \mathrm{~L} \mathrm{Mol}^{-1} \mathrm{Cm}^{-1}$ and $3.6 \times 10-3 \mu \mathrm{g} \mathrm{cm}$ respectively. The system obeys Beer's law in the range of $0.35-3.53 \mathrm{mg} / \mathrm{L}$. The regression coefficient of the Beer's law straight line is 0.338 , and the correlation coefficient is 0.999 . The detection limit of the method is $0.021 \mu \mathrm{g} \mathrm{mL}^{-1}$. Most of the common metal ions generally found associated with copper do not interfere. The repeatability of the method was checked by finding the relative standard deviation. The developed method has been successfully employed for the determination of copper (II) in leafy vegetable and pharmaceutical samples and this method was inter comparison of experimental values using AAS.
\end{abstract}

\section{INTRODUCTION}

Copper is one of the metal ions that play an important role in the biological system. It plays a key role during cell respiration, in the blood of invertebrate animals, and in the formation of hemocyanin, an important respiratory protein, found in the lymph of most animals belonging to Phyla Mollusca and Arthropoda. From the standpoint of human health, its role in three physiological functions is of prime importance. Copper is involved in hemopoiesis and in maintenance of vascular and skeletal integrity in addition to the structure and function of the central nervous system. Copper occurs naturally in most vegetables, meats, and grains. The study of copper in food items is of great concern, because it plays a definitive role in the intrinsic mechanisms regulating vital biological processes [1]. Over exposure to copper causes metallic taste, ptyalism, nausea, vomiting, epigastric burning, and diarrhea. Heavy doses of copper cause a series of systematic toxic effects such as hemolysis, hepatic neurosis, gastrointestinal, bleeding, oliguria azotemia, hemoglobinuria, hematuria, proteinuria, hypertension, tachycardia, convulsions, and coma. When a congenital deficiency in the homeostatic mechanism for copper exists, the metal accumulates in the liver, discrete areas of the brain, the cornea of the eye, and other tissues, causing Wilson's disease. A wide variety of clinical disorders have been associated with a dietary deficiency of copper, which respond to copper therapy. They include anemia, depressed growth, bone disorders, depigmentation of hair or wool, abnormal wool growth, neonatal ataxia, impaired reproductive performance, heart failure, and gastrointestinal disturbances [2]. In view of this, the separation and determination of copper from associated elements is indispensable. For the determination of copper at micro levels there are several frequently adopted methods using analytical techniques such as AAS, ICP-OES, X-ray fluorescence spectroscopy, spectrophotometry, spectrofluorometry, and other such techniques. Among these, the spectrophotometric methods are preferred as they are cheaper and easier to handle and have comparable sensitivity. 
A number of spectrophotometric reagents have been used for the determination of copper (II), but a very few number are used for the separation and determination of it. Thiosemicarbazones are important sulfur- and nitrogen-containing organic reagents, where copper coordinates with these reagents to form stable complexes, it is more stable in divalent state. The metal chelates of these sulfur- and nitrogen-containing organic reagents find a wide range of applications in medicine [3] and agriculture. The reviewed $[4,5]$ literature revealed that only a few thiosemicarbazones were employed for determination of copper (II) [6-45]. Hence, the authors introduced a new reagent, 3m3thylthiophene-2-carbaxaldehyde-3-thiosemicarbazone (3-MTAT), for the selective and spectrophotometric determination of $\mathrm{Cu}$ (II) in leafy vegetable, soils pharmaceutical, and standard alloy samples.

\section{EXPERIMENTAL}

\subsection{Apparatus}

A Shimadzu 2450 UV-VIS spectrophotometer with $1.0 \mathrm{~cm}$ quartz cell is used for absorbance studies. An Elico LI-120 digital $\mathrm{pH}$ meter is used for $\mathrm{pH}$ adjustment. A Perkin-Elmer 170-30 atomic absorption spectrometer is used for the comparison of results. A Nicolet FT-IR 560 Magna spectrometer using $\mathrm{KBr}$ was used to obtain the infrared spectra of the compound (3-MTAT). The Bruker $300 \mathrm{MHz}$ NMR spectrometer was used to obtain the ${ }^{1} \mathrm{H}-\mathrm{NMR}$ spectra of the ligand. The Micro Mass VG $7070 \mathrm{H}$ Mass spectrometer was used to obtain the mass of the 3-MTAT.

\subsection{Reagents and chemicals}

All reagents used conform to analytical reagent grade, unless otherwise stated. 3mehthylthiophene-2-carbaxaldehyde-3-thiosemicarbazone (3-MTAT) is prepared employing the following the procedure. $(3 \mathrm{ml}, 0.0030 \mathrm{~mol})$ of 3-methylthiophene-2-carbaxaldehyde is dissolved in $10 \mathrm{ml}$ of absolute ethanol and mixed in a round bottomed flask with $(0.284 \mathrm{~g}, 0.0030 \mathrm{~mol})$ of thiosemicarbazide dissolved in $20 \mathrm{ml}$ of hot water. The mixture was heated under reflux for 30 minutes and then allowed to cool at room temperature for two hours. The crystals obtained were subjected to filtration, washed with cold ethanol and then recrystalized from ethanol (Scheme I). The melting point was $188-190^{\circ} \mathrm{C}$. 3-MTAT dissolve in N,N-dimethylformamide (DMF) and dimethyl sulphoxide. The characterization of 3-MTAT was carried out by IR ${ }^{1} \mathrm{H}$ NMR and Mass spectroscopy. The IR spectrum of 3-MTAT shows absorption bands around $1485 \mathrm{~cm}^{-1}(\mathrm{C}=\mathrm{S}) 1540$ $\mathrm{cm}^{-1}(\mathrm{C}=\mathrm{N}) 2980 \mathrm{~cm}^{-1}(\mathrm{Sp} 3 \mathrm{C}-\mathrm{H}) 3030 \mathrm{~cm}^{-1}(\mathrm{Sp} 2 \mathrm{C}-\mathrm{H})$ and $3300 \mathrm{~cm}^{-1}$ (-NH). The ${ }^{1} \mathrm{H}$ NMR (DMSO, ppm): $11.4(-\mathrm{N}-\mathrm{H}), 7.6\left(-\mathrm{NH}_{2}\right), 9.85(-\mathrm{sp} 2 \mathrm{C}-\mathrm{H}), 2.6\left(-\mathrm{CH}_{3}\right), 7.2-7.8$ (thiophene) and Mass spectrum of 3-MTAT shows signal at $200(\mathrm{M}+1)$ corresponding to its molecular ion peak. The molecular formula and molecular weight of the reagent $\mathrm{C}_{7} \mathrm{H}_{9} \mathrm{~N}_{3} \mathrm{OS}_{2}$ and 199 is respectively.<smiles>Cc1ccsc1C=O</smiles>

3-methylthiophene-2carbaxaldehyde

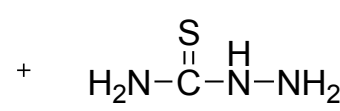

thiosemicarbazide

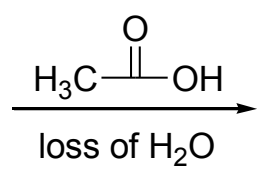

3-methylthiophene-2-carbaxaldehyde -3-thiosemicarbazone

Scheme-1 Preparation of 3-methylthiophene-2-carbaxaldehyde thiosemicarbazone (3-MTAT)

\subsection{Preparation of standard Copper (II) solution}

The stock solution was prepared by dissolving $3.93 \mathrm{~g}$ of copper sulfate pentahydrate $\left(\mathrm{CuSO}_{4}\right.$ $5 \mathrm{H}_{2} \mathrm{O}$ ) in double-distilled water containing a few drops of concentrated sulfuric acid. The solution was made up to $1 \mathrm{~L}$ and standardized by iodometry [46]. This stock solution was diluted further, whenever necessary, with double-distilled water. 


\subsection{Buffer solutions}

Solutions of $1.0 \mathrm{M}$ sodium acetate and 1.0 M acetic acid were prepared in double distilled water. Suitable portions of these solutions were mixed to get the desired $\mathrm{pH}$ of the solution.

\subsection{Analytical procedure for leafy vegetable samples}

The leafy vegetables were brought from the local market during the month of January. The samples were cleaned and dried in open air, protecting them from mineral contamination. The dried sample was pulverized in a mortar for the purpose of analysis, to a convenient size. Ten grams of each powdered sample was taken into a silica crucible, heated to oxidize the organic matter, and ashed at $550{ }^{\circ} \mathrm{C}$ in a muffle furnace for $4-5 \mathrm{~h}$. The ash was dissolved by heating with $10 \mathrm{~mL}$ of $2 \mathrm{~N}$ hydrochloric acid and filtered through an acid-washed filter paper (Whatman no. 41), and then the residue was washed with hot water. The filtrate and washings were collected in a $25 \mathrm{~mL}$ volumetric flask and finally made up to the mark with double-distilled water.

\subsection{Analytical procedure for pharmaceutical samples}

Pharmaceutical samples such as Supradyn, Thesagram-M, Vimgram, and Fersolate were analyzed for copper (II). All of the pharmaceutical samples were brought into solution by adapting the following procedure. The samples were treated separately with concentrated nitric acid on a hot plate, at a low temperature, to avoid violent spurting. The residue of each sample was cooled, and again nitric acid was added. The temperature of the hot plate was kept low to avoid violent spurting. The residue of each sample was cooled, and again nitric acid was added. The temperature of the hot plate was increased to $300{ }^{\circ} \mathrm{C}$. The residue obtained was dissolved in nitric acid $(1: 1)$ and then slowly heated for $2 \mathrm{~h}$ to procure a dry mass. Finally, the residue was dissolved in a minimum amount of double-distilled water. The same solution was quantitatively

transferred into a $500 \mathrm{~mL}$ volumetric flask and then made up to the mark with double-distilled water.

\subsection{Analytical Procedure for Soil samples}

The sample was homogenized in the laboratory using a pestle and mortar and air-dried for approximately $24 \mathrm{~h}$ before analysis. An aliquot of $500 \mathrm{mg}$ of finely pulverized soil was digested with $5 \mathrm{~mL}$ of nitric acid (65\%) in a Teflon vessel. The sample was digested for about $3 \mathrm{~h}$ at $80^{\circ} \mathrm{C}$ and again redigested at $160^{\circ} \mathrm{C}$ for three quarters of an hour. After treating with double distilled water the supernatant liquid was made up to the mark in a $25 \mathrm{~mL}$ standard flask.

\subsection{Analytical Procedure for alloy samples}

The present method was also applied for the determination of cobalt (II) in alloy samples such as high-speed tool samples (BCS 484 and 485) and alloy steel samples (BCS 233 AND 266). About $0.1 \mathrm{~g}$ each of oven dried $\left(110^{\circ} \mathrm{C}\right)$ alloy sample was dissolved in $15 \mathrm{~mL}$ of aquaregia. They were heated to near dryness and the nitrate expelled from the residue using $5 \mathrm{~mL}$ of concentrated hydrochloric acid. Each residue was extracted into double distilled water, separately, and made up to $25 \mathrm{~mL}$ calibrated flask.

\subsection{Recommended procedure}

To an aliquot of solution containing 10.0-150 $\mu \mathrm{g}$ of copper (II) were added buffer of $\mathrm{pH} 6.0$ and $1 \times 10^{-2} \mathrm{M}$ reagent solutions $(0.4 \mathrm{~mL})$; the mixture was made up to $25 \mathrm{ml}$ volumetric flasks. And its absorbance was measured at $430 \mathrm{~nm}$ against to the reagent blank.

\section{RESULTS AND DISCUSSION}

3-methylthiophene-2-carbaxaldehyde-3-thiosemicarbazone (3-MTAT) forms a 1:2 (M:L) complex with copper (II), which is determined from acetic acid sodium acetate ( $\mathrm{pH}$ 6.0) buffer. The light yellow $\mathrm{Cu}$ (II)-3-MTAT complex has a maximum absorbance at $430 \mathrm{~nm}$ and is stable for 46 hours. The conditions for effective and established after studying the effects of various factors, such 
as $\mathrm{pH}$, choice of the solvent, reagent concentration and influence of diverse ions, in order to develop a rapid and sensitive selective spectrophotometric method for the determination of copper (II) in micro levels.

\subsection{Absorption spectra of Cu (II)-3-MTAT complex}

The absorption spectra of the reagent solution against the corresponding solvent as a blank and that of the solution containing cooper (II) complex against the reagent as a blank are recorded in the wavelength range $430 \mathrm{~nm}$. The absorption spectra of the reagent and complex are shown in Figure. 1. The spectra reveal that $\mathrm{Cu}$ (II)-3-MTAT complex shows maximum absorbance at $430 \mathrm{~nm}$ and the reagent shows minimum absorbance at $430 \mathrm{~nm}$. Hence, further absorbance measurements of the $\mathrm{Cu}$ (II)-3-MTAT complex are recorded at $430 \mathrm{~nm}$ against the reagent blank.

\subsection{Effect of $\mathrm{pH}$}

To arrive at the optimum $\mathrm{pH}$ required for full color development, the effect of $\mathrm{pH}$ on the color intensity is studied. In each case, a mixture containing $1.0 \mathrm{~mL}$ of $4 X 10^{-5} \mathrm{M}$ cooper (II), $10.0 \mathrm{~mL}$ of suitable buffer, $1.0 \mathrm{~mL}$ of $4 \times 10^{-4} \mathrm{M} 3$-MTAT solution is taken, and it was made up to the mark with distilled water for $25 \mathrm{ml}$ of standard flask. The same procedure is applied for buffers of different $\mathrm{pH}$ values, ranging from 1.0 to 10.0. The absorbances are measured at $430 \mathrm{~nm}$, using their corresponding reagent blanks. A plot is executed between the $\mathrm{pH}$ and the absorbance, and the same is represented in Figure. 2. The plot shows that there is maximum absorbance and constancy in the $\mathrm{pH}$ range 5.0-7.0. Hence, $\mathrm{pH} 6.0$ is chosen for further studies, considering this as an optimum $\mathrm{pH}$.

\subsection{Effect of reagent concentration}

The effect of reagent concentration is studied using different aliquots containing constant volumes of $1.0 \times 10^{-4} \mathrm{M}$ cooper (II) solution, $10.0 \mathrm{~mL}$ of $\mathrm{pH} 6.0$ buffer solution, $1.0 \mathrm{~mL}$ of $1 \times 10^{-2} \mathrm{M}$ of 3MTAT solution containing different concentrations ranging from $1 \times 10^{-4}$ to $20 \times 10^{-4} \mathrm{M}$, in order to obtain the maximum color formation and it was made up to the mark with double distilled water. The absorbances of the solutions are measured at $430 \mathrm{~nm}$ against their corresponding reagent blanks. It is clearly observed from the absorbance values that a maximum fifteen fold molar excess of the reagent is sufficient to get a maximum color formation of the complex.

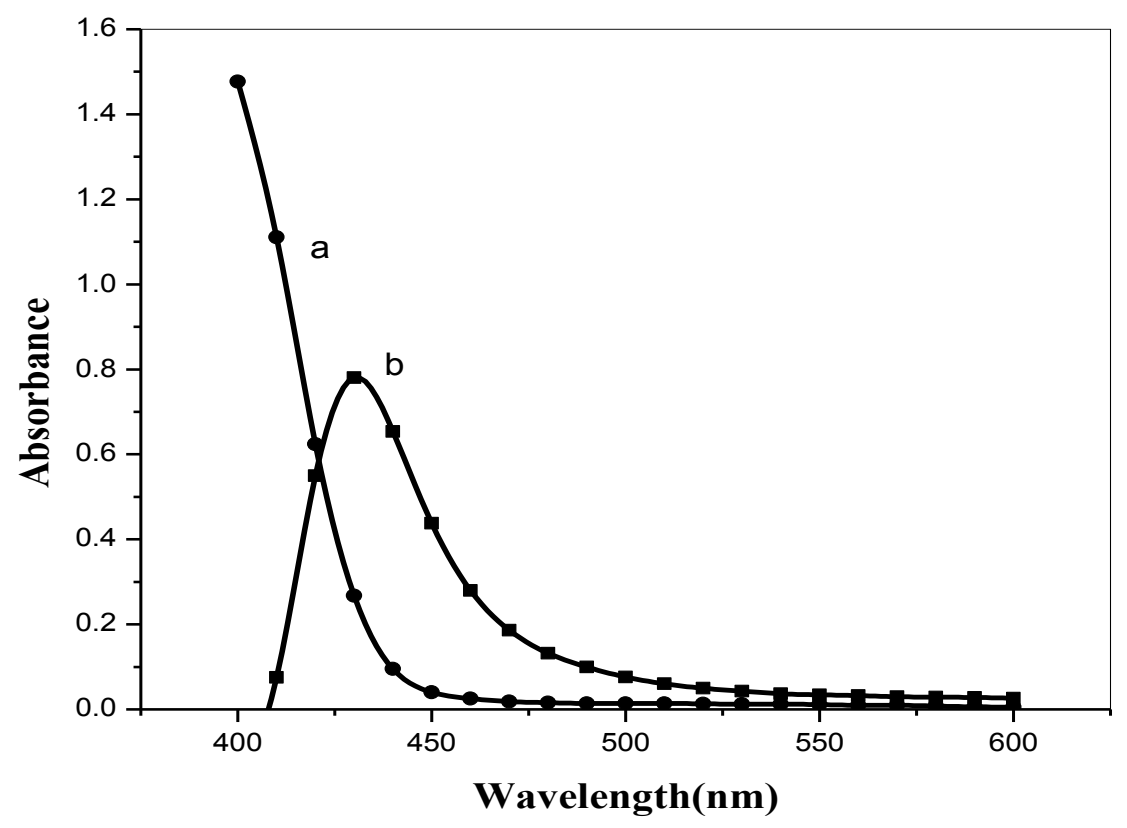

Figure 1. Absorption Spectra of ; a: 3-MTAT Vs Water blank, b: Cu (II) -3-MTAT complex Vs 3MTAT solution, $\mathrm{Cu}$ (II): $8 \times 10^{-5} \mathrm{M}, 3-\mathrm{MTAT}: 4 \times 10^{-4} \mathrm{M}$, pH: 6.0 . 


\subsection{Validity of Beer's law, Molar Absorptivity, Sandells' Sensitivity and Correlation Coefficient for $\mathrm{Cu}(\mathrm{II})-3-\mathrm{MTAT}$ complex}

The $\mathrm{Cu}$ (II)-3-MTAT complex followed Beer's law in the range of 0.35-3.53 ppm. The molar absorptivity of the complex was calculated to be $1.6 \times 10^{4} \mathrm{~L} \mathrm{~mol}^{-1} \mathrm{~cm}^{-1}$, and Sandell's sensitivity of complex obtained from Beer's law data for absorbance, 0.001 , was found to be $0.0036 \mu \mathrm{g} \mathrm{cm}^{-2}$. The correlation coefficient value of the $\mathrm{Cu}$ (II)-3-MTAT complex, with an independent variable as concentration in $\mu \mathrm{g} \mathrm{mL}^{-1}$ and dependable variable as absorbance, was found to be 0.999 . This indicated an excellent linearity between the two variables.

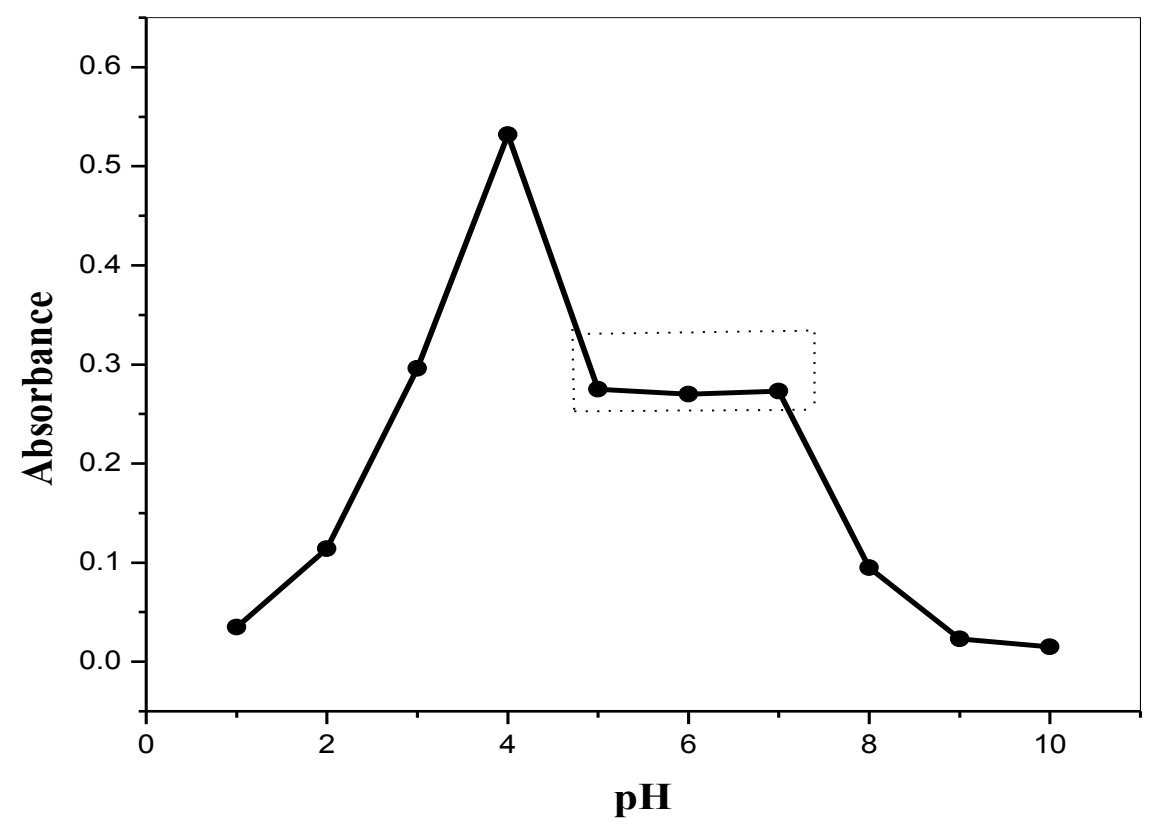

Figure 2. Effect of $\mathrm{pH}$ on the absorbance of $\mathrm{Cu}$ (II) -3-MTAT complex; $\mathrm{Cu}$ (II):4 x10-5 $\mathrm{M}, 3$ MTAT: $4 \times 10^{-4} \mathrm{M}, \lambda \max : 430 \mathrm{~nm}$.

\subsection{Precision, accuracy and detection limit of the method}

To assess the precision and accuracy of the method, determinations are carried out at different concentrations of cooper (II) under optimum conditions. The standard deviation of the method is found to be not more than 0.0038 , and the relative standard deviation was less than 1.7 percent. It is evident from these results that the method is precise, besides being accurate. The detection limit $\mathrm{C}_{\min }$ is determined as the amount of copper (II) corresponding to five times the standard deviation of the blank values, and a value of $0.021 \mu \mathrm{g} \mathrm{mL}-1$ is obtained.

\subsection{Determination of The Composition of Co(II)-3-MTAT complex}

The composition of the $\mathrm{Cu}$ (II) complex with 3-MTAT was studied using Job's method of continuous variation, and the mole ratio method [16]. Spectrophotometric investigation of the metal complex was conducted to obtain the composition of the complex. The composition of the complex was established by Job's method of continuous variation. Equimolar solutions of Cu (II) and 3MTAT $\left(2 \times 10^{-4} \mathrm{M}\right)$ were prepared. The metal and reagent solutions were mixed in different proportions, keeping the total volume constant at $10.0 \mathrm{ml}$. To each solution, $10.0 \mathrm{ml}$ of buffer $(\mathrm{pH}$ 6.0) solution was added and it was made up to the mark with distilled water. The absorbance values of the $\mathrm{Cu}$ (II)-3-MTAT were recorded at $430 \mathrm{~nm}$, against their respective reagent blanks. From the above experimental results, it is evident that one mole of Copper (II) reacts with two mole of 3MTAT, showing the composition of the complex to be $1: 2$. This composition was verified using the molar ratio method. From jobs continuous variation method the stability constant of the complex found to be $1.74 \times 10^{11}$. 


\subsection{Effect of foreign ions}

The tolerance limit means the limit within which the foreign ion cannot be interfered with for the determination of $\mathrm{Cu}$ (II). In order to assess the possible analytical applications of this color reaction, the effect of some foreign ions are also examined by carrying out determinations of $75 \mu \mathrm{g}$ of copper (II) with a known amount of the ion in question using the recommended general procedure. The criterion for interference is a variation of more than \pm 2 percent in absorbance from the expected value for copper (II) alone. In the case of some interfering ions, an increased tolerance limit is achieved by the addition of masking agents, such as thiosulfate, fluoride, tartrate or thiocyanate. Increasing the amount of masking agents proportionately could mask a higher amount of interfering ions. In this study, cations like $\mathrm{As}(\mathrm{III}), \mathrm{As}(\mathrm{V}), \mathrm{Mg}(\mathrm{II}), \mathrm{Mn}$ (II), $\mathrm{Zr}$ (IV), $\mathrm{Sb}(\mathrm{III}), \mathrm{Ca}(\mathrm{II})$, $\mathrm{Sr}(\mathrm{II}), \mathrm{Ba}(\mathrm{II})$, and $\mathrm{Tl}(\mathrm{III})$ do not interfere, when present up to $5500 \mu \mathrm{g}$ and cations like $\mathrm{Bi}(\mathrm{III})$, $\mathrm{Hg}(\mathrm{II}), \mathrm{Be}(\mathrm{II}), \mathrm{Th}(\mathrm{VI}), \mathrm{U}(\mathrm{VI}), \mathrm{Al}(\mathrm{III})$, and $\mathrm{V}(\mathrm{V})$ are tolerated up to $3000 \mu \mathrm{g}$, but $\mathrm{Cd}(\mathrm{II}), \mathrm{Co}(\mathrm{II})$, $\mathrm{Ni}(\mathrm{II}), \mathrm{Zn}(\mathrm{II}), \mathrm{Fe}(\mathrm{III}), \mathrm{Mo}(\mathrm{VI})$ and $\mathrm{Pd}(\mathrm{II})$ do interfere with the determination of copper (II) when present in more than $2000 \mu \mathrm{g}$. The interference of Co (II) can be eliminated by using $1.0 \mathrm{~mL} 0.2 \%$ oxalate as a masking agent. Fe (II) \& Fe (III) are masked with $1.0 \mathrm{~mL}$ of $3 \%$ of sodium fluoride. The interference of $\mathrm{Zn}$ (II), Cd (II) can be eliminated by using $1.0 \mathrm{~mL}$ of $0.5 \%$ of thiosulphate solution. Anions like fluroride, thiocyanate, thiosulfate and thiourea do not interfere when present up to $3000 \mu \mathrm{g}$ with the determination in the method. Citrate and borate are tolerated up to $1500 \mu \mathrm{g}$. Oxalate and phosphate interferes, even when present in trace amounts. EDTA masks copper (II) completely in the present determination.

\subsection{Applications}

The developed spectrophotometric method for copper (II) is applied for its determination in real samples such as leafy vegetable, soil, Pharmaceutical and standard alloy samples.

\subsection{Determination of copper (II) in leafy vegetable samples}

The present method was applied for the determination of copper (II) in leafy vegetables samples. Each aliquot was analyzed for copper (II) by the recommended procedure which was given in the meterials and methods section. Copper (II) present in vegetable samples was determined from the calibrated plot (Beer's law plot) using 3-MTAT and the results checked by atomic absorption spectrometry Table 1.

Table.1. Determination of Copper(II) in leafy vegetables

\begin{tabular}{|l|c|c|c|c|c|}
\hline \multicolumn{1}{|c|}{ Leafy Vegetables } & $\begin{array}{c}\text { Amount added } \\
(\mu \mathrm{g} / \mathrm{g})\end{array}$ & \multicolumn{2}{|c|}{$\begin{array}{c}\text { Amount of Cu (II) } \\
\text { found }\end{array}$} & SD & $\% \mathrm{RSD}$ \\
\cline { 3 - 6 } & & $\begin{array}{c}\text { AAS } / \mathrm{g}) \\
\text { Method }\end{array}$ & $\begin{array}{c}\text { Present } \\
\text { Method }\end{array}$ & & \\
\hline cucumber (Cucumis sitivas) & 10.00 & 10.52 & 10.51 & 0.03 & 0.28 \\
\hline green peas (Pisum sativum) & 10.00 & 11.15 & 11.14 & 0.05 & 0.43 \\
\hline fresh bean (Dolichos lablab) & 10.00 & 10.88 & 10.87 & 0.04 & 0.37 \\
\hline $\begin{array}{l}\text { white radish (Raphanus } \\
\text { sativus) }\end{array}$ & 10.00 & 14.21 & 14.20 & 0.06 & 0.42 \\
\hline
\end{tabular}

a Average of four determinations

\subsection{Determination of copper (II) in soil samples}

The present method was applied for the determination of copper (II) in soil samples. Each aliquot was analyzed for copper (II) by the recommended procedure which was given in the experimental section. Copper (II) present in soil samples was determined from the calibrated plot (Beer's law plot) using 3-MTAT and the results checked by atomic absorption spectrometry Table 2. 


\subsection{Determination of Copper (II) in pharmaceutical samples}

The present method was applied for the determination of copper (II) in Pharmaceutical samples.. Each aliquot was analyzed for copper (II) by the recommended procedure which was given in the experimental section. Copper (II) present in soil samples was determined from the calibrated plot (Beer's law plot) using 3-MTAT and the results checked by atomic absorption spectrometry Table 3 .

Table.2. Determination of Copper (II) in soil samples

\begin{tabular}{|l|c|c|c|}
\hline \multirow{2}{*}{ Soil Sample Site } & \multicolumn{2}{|c|}{ Amount of Cu $(\mathrm{II})$ found $^{\mathrm{a}}(\mu \mathrm{g} / \mathrm{g})$} & \multirow{2}{*}{ \% Error } \\
\cline { 2 - 3 } & AAS Method & Present Method & \\
\hline Kadapa & 23.95 & 23.68 & 1.12 \\
\hline Mangampeta & 23.24 & 22.93 & 1.33 \\
\hline Produtur & 21.06 & 20.85 & 0.99 \\
\hline Yeeraguntla & 22.32 & 21.99 & 1.47 \\
\hline Mydukur & 21.43 & 21.39 & 0.18 \\
\hline
\end{tabular}

a Average of four determinations

Table.3. Determination of Copper (II) in Pharmaceutical samples

\begin{tabular}{|c|c|c|c|c|}
\hline \multirow[t]{2}{*}{ Pharmaceutical samples } & \multicolumn{2}{|c|}{ Amount of $\mathrm{Cu}(\mathrm{II})$ found $^{\mathrm{a}}(\mu \mathrm{g} / \mathrm{g})$} & \multirow[t]{2}{*}{ SD } & \multirow[t]{2}{*}{$\%$ RSD } \\
\hline & AAS Method & Present Method & & \\
\hline Supradyn (Roche Chemicals, India) & 0.86 & 0.85 & 0.011 & 1.29 \\
\hline $\begin{array}{l}\text { Theragran-M (Sarabhai Chemicals, } \\
\text { India) }\end{array}$ & 2.00 & 1.99 & 0.013 & 0.65 \\
\hline $\begin{array}{l}\text { Vimgram (Sarabhai Chemicals, } \\
\text { India) }\end{array}$ & 1.00 & 0.99 & 0.012 & 1.21 \\
\hline Fersolate (Glaxo, India) & 0.66 & 0.65 & 0.011 & 1.69 \\
\hline
\end{tabular}

a Average of four determinations

\subsection{Determination of Copper (II) in standard alloy samples}

The present method was also applied for the determination of copper (II) content in standard alloy samples. The amount of copper (II) present in each one of the sample solutions was determined from a calibrated plot and the results checked by direct Atomic Absorption Spectrometer Table 4. 
Table. 4. Determination of Copper (II) in standard alloys

\begin{tabular}{|c|c|c|c|c|}
\hline \multirow{2}{*}{ Standard alloy } & \multirow[b]{2}{*}{ Composition } & \multicolumn{2}{|c|}{$\begin{array}{l}\text { Amount of } \mathrm{Cu}(\mathrm{II}) \\
\text { found }^{\mathrm{a}}(\mu \mathrm{g} / \mathrm{g})\end{array}$} & \multirow[t]{2}{*}{$\%$ Error } \\
\hline & & $\begin{array}{l}\text { AAS } \\
\text { Method }\end{array}$ & $\begin{array}{l}\text { Present } \\
\text { Method }\end{array}$ & \\
\hline NKK-1021-Alloy & $\begin{array}{l}\mathrm{Si}, 5.56 \% ; \mathrm{Cu}, 2.72 \% ; \mathrm{Zn}, 1.76 \% ; \\
\mathrm{Fe} 0.99 \% ; \mathrm{Mg}, 0.29 \% ; \mathrm{Mn} 0.20 \% \text {; } \\
\mathrm{Ni}, 0.14 \% ; \mathrm{Cr} 0.03 \%\end{array}$ & 1.02 & 1.00 & 1.96 \\
\hline NBS-SRM - 54 D & $\begin{array}{l}\text { Sn } 88.5 \% ; \mathrm{Sb} 7.04 \% ; \mathrm{Cu} 3.62 \% ; \mathrm{Pb} \\
0.62 \% ; \mathrm{As} 0.08 \% \text {; Bi } 0.04 \% ; \mathrm{Fe} 0.03 \% \text {; } \\
\mathrm{Ag}-0.003 \% \text {;i }-0.002 \%\end{array}$ & 1.02 & 1.01 & 0.98 \\
\hline $\begin{array}{l}\text { Alloy steel (BCS } \\
\text { 233) }\end{array}$ & $\begin{array}{l}\mathrm{Cu}, 5.09 ; \mathrm{Co}, 23.4 ; \mathrm{Ni} 11.22 ; \mathrm{Sn}, 7.95 \\
\mathrm{Mn}, 0.235 \text {. }\end{array}$ & 5.00 & 4.98 & 0.40 \\
\hline $\begin{array}{l}\text { Alloy steel (BCS } \\
\text { 266) }\end{array}$ & $\begin{array}{l}\mathrm{Cu}, 3.33 ; \mathrm{Co}, 23.4 ; \mathrm{Ni}, 13.3 \\
\mathrm{Al}, 7.95 \text {. }\end{array}$ & 3.30 & 3.28 & 0.60 \\
\hline $\begin{array}{l}\text { Aluminum base } \\
\text { alloy (BCS 216/1) }\end{array}$ & $\begin{array}{l}\mathrm{Cu}, 4.42 ; \mathrm{Mn}, 0.73 ; \mathrm{Fe}, 0.40 \\
\mathrm{Zn}, 0.11 ; \mathrm{Ti}, 0.10\end{array}$ & 4.40 & 4.36 & 0.90 \\
\hline $\begin{array}{l}\text { Copper base alloy } \\
\text { (BCS 207) }\end{array}$ & $\mathrm{Cu}, 86.84 ; \mathrm{Sn}, 9.8 ; \mathrm{Zn} 2.53 ; \mathrm{Pb}, 0.41$ & 86.76 & 86.70 & 0.06 \\
\hline $\begin{array}{l}\text { Copper base alloy } \\
\text { (BCS 179) }\end{array}$ & $\begin{array}{l}\mathrm{Cu}, 58.8 ; \mathrm{Zn}, 33.9 ; \mathrm{Sn}, 1.75 ; \mathrm{Al}, 1.62 ; \\
\mathrm{Mn}, 1.03 ; \mathrm{Ni}, 1.01 ; \mathrm{Fe}, 0.91\end{array}$ & 58.72 & 58.65 & 0.11 \\
\hline BAS-20 & $\begin{array}{l}\text { Cu.4.10; Ni1.93; Fe0.43; Mn 19; Si 0.29; } \\
\text { Mg 1.61; Rest Al }\end{array}$ & 1.20 & 1.19 & 0.83 \\
\hline BAS-85 & $\begin{array}{l}\text { Cu.0.90; Ni0.91; Feb1.15;Mn 0.02; } \\
\text { Si 2.04; Mg 0.18; Zn 0.01; Rest Al }\end{array}$ & 0.70 & 0.69 & 1.4 \\
\hline
\end{tabular}

a Average of four determinations

\section{CONCLUSION}

A thorough survey of the literature reveals that many thiosemicarbazones are utilized for the determination of copper (II). Studies upon the use for 3-methylthiophene-2-carbaxaldehyde thiosemicarbazone as an analytical reagent are however limited. The present investigations are carried out with a view to test the potential of 3-MTAT as a complexing agent for copper (II) and its subsequent determination by spectrophotometry. The selectivity of this method is enhanced by using masking agents for Ni (II), Cd (II), Co (II), Fe (III) and Zn (II). Finally, it is established that this method is suitable for the determination of copper (II) in vegetable, soil, pharmaceutical and standard alloy samples.

\section{Acknowledgements}

My sincere thanks to Sri Krishnadevaraya University, Anantapur, A.P, India. For conducting this research programme.

\section{References}

[1] Malvankar P. L. and Shinde V. M. Analyst 116, (1991), 1081-1084.

[2] Walravens P. A. Clinil Chem. 26, (1980) pp. 185-189.

[3] Hall I. H. , Lackey C.B. , Kistler T.D., Durham R. W. , Jouad E. M. , Khan, M. Thanh X. D., Djebbarsid S. , Benali Baitich O. and Bouet G.M. Pharmazie 55, (2000), 937-941.

[4] Singh R. B. , Garg G. S. and Singh R. P., Talanta, 25, (1978), 619-632. 
[5] Casas J. S., Garcia-Tasende M. S., and Sordo J. , Coordation. Chemistry. Review. 209 (2000), 197-261.

[6] D. V. Khasnis, and V. M. Shinde, J Indian Chem.Soc., 59 (6), (1982), 812-814.

[7] Jadhav V. A. , and Vandre A. G., J Indian Chem.Soc. 72, (1995) 747-748.

[8] Thimmaiah K. N. , Sanke Gowda H. S. , and Ahmed M., Indian Journal of Chemistry. 22, (1983), 690-692.

[9] Khasnis D. V. , and Shinde V. M. J Indian Chem.Soc.. 61 (1984), 275-277.

[10] Tongsen M. , Meng M, L. , Congde H. , Kuaizhi L. , Zhenghao L. , and Daxuesuebao Z. Ziaru Keruebau, 31, (1999), 70-72.

[11] Lopez-de-Alba. P. and Loper-Martiney. L., Bol. Soc. Chil. Quim., 44, (1999), 469-477.

[12] Desai J. M. and Desai K. K. Asian Journal. Chemistry. 11 (1999) 1311-1316.

[13] Patel A. L. and Patel I. J. J. Inst. Chem. (Indian) 72, (2000) 8-8.

[14] Lokhande R. S., Poman S. V. and Kapadi H. R. . Asain J. Chem., 13, (2001) 1222-1224.

[15] Reddy B. K., Kumar J. R., Reddy K. J., Sarma L. S., and Reddy A. V., Anal Scien. 19, (2003), 423-428.

[16] Ghazy S.E., El-shazy R.M., El-shahawi M.S., Al-Hazni G.A.A. and El-Asmy A.A., J. Iran. Chem. Soc., 3, (2006) 140.

[17] Prasad N.B.L., Reddy K.H. and Reddy T.S.R., Indian J. Chem., 42 (2003) 112.

[18] Sayajirao M., Prasad N.B.L. and Reddy K.H., Indian J. Chem., 45A, (2006) 1659.

[19] Reddy K.H. and Prasad N.B.L., Indian J. Chem., 43A, (2004) 111.

[20] Lokhande R.S., Nirupama S. and Chaudhary A.B., Asian J. Chem., 14 (2002) 149.

[21] Atalay T.and. Akgemci E.G, Turk. J. Chem., 22, (1998) 123.

[22] Narayana S.L., Reddy K.J., Reddy S.A., Subbarao Y. and Reddy A.V., Food Anal. Methods, 1, (2008) 293.

[23] G. Ramanjaneyulu, P.R. Reddy, V.K. Reddy and T.S. Reddy, The Open Anal. Chem. J., 2, (2008) 78 .

[24] Hererra J.M.C., Rojas S.F., Ojeda B.C.,. Detores G.A and Pavon C.J.M, J. Flow Inj. Anal., $17,(2000) 65$.

[25] Kato T.and Hasegawa A., Bunseki Kagaku, 31, (1982) 579.

[26] Jadhav V.A. and Vandre, J. Indian Chem. Soc., 69, (1992) 791.

[27] Karthikeyan J., Naik P.P. and Shetty A.N., Environ. Monit. Assess., 176, (2011) 419.

[28] Reddy K.J., Kumar J.R., Narayana S.L., Ramachandraiah C., Triveni T. and Reddy A.V., Environ. Monit. Assess., 124, (2007) 309.

[29] Akgemci E.G. and Atalay T., Turk. J. Chem., 24, (2000) 89.

[30] Bingol H., Akgemci E. and Atalay T., J. Anal. Chem., 61 (2006) 1015.

[31] Rao G.P.C., Seshaiah K., Rao Y.K. and Wang, M.C. J. Agric. Food Chem., 54, (2006) 2868.

[32] Babu S.V. and Reddy K.H., J. Indian Chem. Soc., 83 (2006) 20.

[33] Konstantinovic S.S., Radovanovic B.C., Todorovic Z.B and Ilic, S.B. J. Serb. Chem. Soc., 72 (2007) 975.

[34] Archana R.K. and Thakkar N.V., J. Scient. Ind. Res., 63, (2004) 283. 
[35] Jadhav V.A. and. Kulkarni M.U, J. Indian Chem. Soc., 69 (1992) 287.

[36] Jadhav V.A. and Vandre A.G., J. Indian Chem. Soc., 75 (1995) 747.

[37] Jain V.K., Sait S.S., Shrivastav P.and Agarwal Y.K., Talanta, 45, (1997) 397.

[38] Khalifa M.E., Akl M.A. and Ghazy S.E., Chem. Pharm. Bull. (Tokyo), 49 (2001) 664.

[39] Reddy K.H., Prasad N.B.L. and Reddy T.S., Talanta, 59 (2003) 425.

[40] Chamjangli M.A., Panah S.S. and Goudarzi N., Sens. Actuators B, 138 (2009) 251.

[41] Morales M.L. and Toral I., Miner. Eng., 20 (2007) 802.

[42] Prasad N.B.L., Reddy K.H. and Reddy T S., J. Indian Chem. Soc., 83 (2006) 485.

[43] Vareda E., Rios A. and Valcarcel M., Analyst, 122 (1997) 85.

[44] Sarma L.S., Kumar J.R., Reddy K.J. and Reddy A.V., J. Agri. Food Chem., 53 (2005) 5492.

[45] Khuhawar M.Y. and Lanjwani S.N., Talanta, 46 (1998) 485.

[46] Vogel, A. I. A Textbook of QuantitatiVe Inorganic Analysis; Longman Green: London, U.K., 1961. 